Folia Historica Cracoviensia, 22: 2016, s. 535-557

DOI: http://dx.doi.org/10.15633/fhc.2095

Cezary Taracha

Katolicki Uniwersytet Lubelski Jana PawŁa II

\title{
Francesco Arcelli, włoski zakonnik na służbie burbońskiej Hiszpanii
}

Stulecie XVIII to czas trudnych wyzwań tak dla życia zakonnego w ogóle, jak i dla konkretnych zgromadzeń. Przypomnijmy takie wydarzenia, jak likwidacja redukcji paragwajskich, wypędzenie jezuitów z Portugalii i Hiszpanii, rozwiązanie Towarzystwa Jezusowego, likwidacja setek domów zakonnych w ramach reform józefińskich czy okrutne represje wobec duchowieństwa z czasów rewolucji francuskiej. Mimo prób kwestionowania obecności zakonów w przestrzeni publicznej odgrywały one nadal istotną rolę w wielu obszarach życia społecznego, w świecie kultury i edukacji. Oprócz posługi właściwej zakonnym charyzmatom, spotykamy zakonników na królewskich dworach, pełniących ważne funkcje w administracji państwowej, w dyplomacji, na uniwersytetach, w szkołach, w instytucjach dobroczynnych i kulturalnych.

Francesco Arcelli należał do tej właśnie kategorii osób duchownych, które łączyły, z lepszym lub gorszym skutkiem, służbę Bożą z zaangażowaniem o charakterze świeckim, publicznym i państwowym. W epoce nowożytnej tego rodzaju aktywność osób duchownych nie była niczym nadzwyczajnym, zwłaszcza w katolickiej monarchii hiszpańskiej.

\section{Duchowni w nowożytnej Hiszpanii}

Monarchia hiszpańska, tak pod rządami Habsburgów (XVI-XVII w.), jak i Burbonów (xviII w.), była państwem wyznaniowym. Wraz z upływem czasu zmieniały się uwarunkowania i formy współpracy pomiędzy władzą świecką a Kościołem katolickim, ale ta ścisła koegzystencja pozostawała ustrojowym fundamentem 
Hiszpanii, a każdy król nosił dumnie tytuł „el Rey Católico”, nadany pod koniec XV wieku Ferdynandowi Aragońskiemu oraz Izabeli Kastylijskiej. Ta szczególna i uprzywilejowana pozycja katolicyzmu miała różnorodne konsekwencje, wpływając na organizację i funkcjonowanie państwa, jego politykę wewnętrzną (dążenia do religijnej homogeniczności społeczeństwa), jak i zagraniczną (obrona katolicyzmu na arenie międzynarodowej). Stawiała również w szczególnej roli duchowieństwo. Problematyka ta jest doskonale znana w historiografii, choć rzecz jasna wciąż nie brakuje w tej kwestii kontrowersji i dyskusji, zwłaszcza dotyczących zakresu ingerencji instytucji kościelnych w sfery państwową i świecką. Chciałbym w tym miejscu przywołać dla przykładu znakomite prace poświęcone tym właśnie zagadnieniom pióra Julio Caro Baroja ${ }^{2}$, zwłaszcza zaś świetne studium jego autorstwa Pan inkwizytor ${ }^{3}$. Publikacje tego rodzaju ukazują ogromną rolę duchowieństwa świeckiego i zakonnego nie tylko w sprawach stricte religijnych, duszpasterskich czy misyjnych, ale również w edukacji, kulturze, nauce i polityce.

Podstawowym obszarem aktywności hiszpańskiego duchowieństwa epoki nowożytnej była oczywiście służba boża, duszpasterstwo, katechizacja i praca misyjna. Reformy przeprowadzone w Kościele hiszpańskim w drugiej połowie XV i pierwszej połowie XVI wieku doprowadziły do umocnienia sił moralnych oraz podniesienia poziomu wykształcenia duchownych. Ożywieni religijnym zapałem księża i zakonnicy zwalczali prądy reformacyjne, pisali teologiczne i filozoficzne traktaty, dzieła mistyczne. Fundowali nowe zgromadzenia i dzieła charytatywne. Podjęli gigantyczne zadanie ewangelizacji Nowego Świata, organizując działalność misyjną, a następnie budując fundamenty i struktury kościelne na terenie kolonii położonych w różnych częściach globu.

Inny ważny odcinek ich działalności to kształcenie młodego pokolenia i edukacja hiszpańskich elit. Dominikanie, jezuici czy pijarzy tworzyli nowe paradygmaty nauczania i edukacji. Zapisali się również złotymi zgłoskami w dziejach hiszpańskiej kultury, sztuki, literatury, muzyki.

Znaczenie i prestiż stanu duchownego powodowały, że przyciągał on ludzi wywodzących się z różnych grup społecznych. Dla jednych służba Bogu i Kościołowi stanowiła wypełnienie powołania, dla innych drogę realizacji życiowej kariery i podniesienia statusu społecznego. Sytuacja ta znalazła odzwierciedlenie $\mathrm{w}$ publicystyce, literaturze satyrycznej, a nawet $\mathrm{w}$ popularnych powiedzeniach,

Tytuł „los reyes católicos” nadał w 1493 roku papież Aleksander vi.

Julio Caro Baroja (1914-1995), hiszpański historyk, antropolog i lingwista.

Zob. J. Caro Baroja, Pan inkwizytor, tłum. i wstęp C. Taracha, Lublin 2000. 
jak choćby: Iglesia o mar o casa real quien quiera medrar („Kościół, morze albo dwór [w Madrycie], kto chce żyć w dobrobycie").

Nic więc dziwnego, że wielu duchownych znajdowało swoje miejsce na dworze królewskim jako doradcy czy spowiednicy oraz w instytucjach administracji państwowej. Mam tu na myśli nie tylko Radę ds. Inkwizycji (Consejo de la Inquisición), ale również inne centralne organy monarchii, consejos czy secretarías. Niektórzy z nich, jak choćby jezuita Johannes Eberhard Nithard ${ }^{4}$ za panowania Karola II czy kardynał Giulio Alberoni za Filipa v, mieli decydujący wpływ kierunki polityki monarchii hiszpańskiej.

\section{Cudzoziemcy na służbie Hiszpanii}

Powszechną praktyką, zwłaszcza w XVIII wieku, było powierzanie znaczących stanowisk w administracji państwowej (zarówno tej centralnej, jak i lokalnej, cywilnej i wojskowej) cudzoziemcom. W przypadku Hiszpanii można wskazać na takie postaci, jak wspomniany już kardynał Alberoni (Włoch), baron Ripper$\mathrm{da}^{5}$ (Holender, który w zależności od koniunktury zmieniał wyznania, a nawet religie, kalwinizm na katolicyzm, a następnie chrześcijaństwo na islam), Ricardo Wall $^{6}$ (Irlandczyk) czy Girolamo Grimaldi ${ }^{7}$ (Włoch). Wszyscy oni dotarli na szczyty władzy politycznej, kreując i realizując cele polityki zagranicznej burbońskiej monarchii.

Nie dysponujemy całościowymi opracowaniami dotyczącymi skali tego zjawiska. Istnieją natomiast publikacje dotyczące konkretnych kategorii zawodowych

4 Johans Eberhard Nithard (1607-1681), austriacki jezuita, kardynał, spowiednik królowej Marianny, wielki inkwizytor. Por. I. Pinedo, H. Platzgummer, Niedhard (Nithard), Johann Eberhard, [w:] Diccionario histórico de la Compañía de Jesús, vol. 3, ed. Ch. E. O’Neill, J. M. Domínguez, Roma-Madrid, s. 2818-2819.

5 Johan Willem Ripperdá (1680-1737), holenderski awanturnik, dyplomata i polityk, w latach 1725-1726 sekretarz stanu odpowiedzialny za politykę zagraniczną Hiszpanii. Por. D. Ozanam, Les diplomates espagnols du XVIII siècle. Introduction et répertoire biographique (1700-1808), Madrid-Bordeaux 1989, s. 413-414.

6 Ricardo Wall y Devreux (1694-1777), wojskowy, dyplomata i polityk pochodzenia irlandzkiego na służbie Hiszpanii, w latach 1754-1763 pierwszy sekretarz stanu. Por. D. Ozanam, Les diplomates espagnols du XVIII siècle..., dz. cyt., s. 471-472.

7 Pablo Jerónimo Grimaldi y Pallavicini (1709-1789), włoski dyplomata i polityk na służbie hiszpańskiej, w latach 1763-1776 pierwszy sekretarz stanu. Por. D. Ozanam, Les diplomates espagnols du XVIII siècle..., dz. cyt., s. 287-288. 
cudzoziemców na służbie Hiszpanii oraz poddanych innych państw przebywających czasowo na Półwyspie Iberyjskim. Mam tu na myśli kolonistów pochodzących z różnych części Europy, których sprowadzano do Hiszpanii w celu zasiedlania pustek, zwłaszcza na terenie Andaluzji (Sierra Morena). Druga znacząca grupa cudzoziemców na służbie króla katolickiego to wojskowi, których rekrutowano do różnych formacji hiszpańskich, a zwłaszcza do elitarnej Gwardii Walońskiej. Warto tu na marginesie dodać, że w XVIII wieku pojawiały się projekty sprowadzania kolonistów i żołnierzy z dalekiej Polski. Ich autorami byli hiszpańscy dyplomaci (np. wicehrabia de la Herreria ${ }^{8}$ ) i polscy wojskowi (Wojciech Dzierżanowski) ${ }^{9}$. Inną kategorią obcokrajowców, których pracę ceniono w zapóźnionej pod względem technologicznym i przemysłowym Hiszpanii, byli specjaliści, inżynierowie, wykwalifikowani robotnicy, np. w zakresie budownictwa okrętowego, produkcji broni, niektórych gałęzi przemysłu.

Nie brakowało cudzoziemców również w hiszpańskiej służbie dyplomatycznej i konsularnej. Cytowany już Didier Ozanam podaje, że wśród 167 kierowników placówek dyplomatycznych aż 47 (28 proc.) to cudzoziemcy (Włosi, Francuzi, Irlandczycy, Niemcy, Holendrzy ${ }^{10}$.

Znaczący był również udział duchownych w służbach zagranicznych państwa. Interesujące dane w tym zakresie przynoszą badania o charakterze prozopograficznym dotyczące hiszpańskiego korpusu dyplomatycznego i konsularnego w XVIII wieku. Analizując pochodzenie społeczne i zawodowe szefów placówek dyplomatycznych różnych kategorii, Didier Ozanam doszedł do wniosku, że duchowni stanowili 8,38 proc. w grupie liczącej 167 osób. Bardzo wymowne są również ustalenia odnoszące się do rządów poszczególnych władców z dynastii Burbonów. Okazuje się, że za panowania Filipa v (1700-1746) oraz Karola III (1759-1788) udział duchownych wśród szefów placówek dyplomatycznych przekraczał 1o proc. ${ }^{11}$ Francesco Arcelli przynależał do obu wymienionych grup. Był duchownym, zakonnikiem, a równocześnie cudzoziemcem, pozostającym na służbie Hiszpanii.

8 Álvaro de Navia Osorio y Bellet, wicehrabia de la Herreria (1728-1788), hiszpański wojskowy i dyplomata. Przebywał na placówkach w Rosji, Holandii, Neapolu i Turynie. Por. D. Ozanam, Les diplomates espagnols du XVIII siècle..., dz. cyt., s. 364-365.

9 C. Taracha, El proyecto de llevar colonos polacos a España en 1772, [w:] „Europa del Centro $y$ del Este y el Mundo Hispánico". Simposio Internacional de Hispanistas. Cracovia 26-28 de octubre de 1995, Cracovia 1996, s. 47-57.

10 Zob. D. Ozanam, Les diplomates espagnols du XVIII siècle..., dz. cyt., s. 30.

${ }_{11}$ Zob. D. Ozanam, Les diplomates espagnols du XviII siècle..., dz. cyt., s. 35. 


\section{Francesco Arcelli nieznany}

Analizując dostępne materiały źródłowe oraz nieliczne publikacje jemu poświęcone, można nakreślić szkic biograficzny Arcellego, ukazać podstawowe obszary jego aktywności zakonnej i świeckiej. Warto jednak posłużyć się tą właśnie biografią do sformułowania bardziej ogólnych pytań dotyczących tej szczególnej płaszczyzny zetknięcia się sfer sacrum i profanum, zasad moralnych i pragmatyki władzy, jaką jest polityka oraz jej instrument $\mathrm{w}$ relacjach międzynarodowych, czyli dyplomacja. Dlaczego i w jakich okolicznościach osoby duchowne, w tym zakonnicy, decydowali się (albo byli delegowani) na przekroczenie Rubikonu i zanurzenie się we wzburzonych odmętach wielkiej polityki, w której bardzo często racje Niccolò Machiavellego górowały nad argumentami Baltasara Graciána, nie mówiąc o bardziej radykalnych teologach i moralistach? W jakich formach i postawach to zaangażowanie się wyrażało? I wreszcie, jakie niosło konsekwencje $\mathrm{w}$ obszarze duchowym, etycznym i politycznym? Przypadek ojca Arcellego jest tu, jak się wydaje, znakomitym odzwierciedleniem jednego z możliwych scenariuszy.

Kim zatem był Francesco Arcelli? Co wiemy na temat jego życia, posługi zakonnej oraz aktywności dyplomatycznej? Niestety, nasza wiedza w tym zakresie nie jest zbyt duża. Jak dotychczas nie doczekał się swego biografa, dysponujemy jednak kilkoma publikacjami historyków z różnych krajów (Włochy, Hiszpania, Rosja i Polska). Dotyczą one przede wszystkim jego zaangażowania w sprawy polityczne i aktywności dyplomatycznej w służbie Parmy i Hiszpanii.

Pierwszą próbą odniesienia się do tego zagadnienia była publikacja Marii d’Amato z 1922 roku, która dotyczyła misji Arcellego w Rosji ${ }^{12}$. Wzmianki na ten temat znajdują się jeszcze w kilku innych opracowaniach historyków włoskich, ale nie wnoszą nowych ustaleń w tej kwestii ${ }^{13}$. Pewne informacje na temat Arcellego znajdują się również w pracach badaczy hiszpańskich, takich jak Ciriaco Pérez Bustamante $^{14}$ czy Mario Rodriguez Polo ${ }^{15}$. W historiografii rosyjskiej na uwagę

12 Zob. M. d'Amato, Un teatino diplomatico del secolo XVIII. Contributto alla storia delle relazioni tra Italia e la Russia, Napoli 1922.

13 Zob. N. Rocca, Un diplomatico piacentino Alla corte di Pietro il Grande, „Liberta”, 31.01.1967, s. 5; M. di Salvo, Italia, Russia e mondo slavo. Studi filologici e letterari, a cura di A. Alberti i in., Firenze 2011, s. 191.

${ }^{14}$ Por. przypis 29.

15 Zob. M. Rodríguez Polo, El duque de Liria a su paso por Polonia, „Eslavística Complutense” 8 (2008), s. 207-231. 
zasługują przede wszystkim publikacje Natalii Terekhovej ${ }^{16}$, która bada relacje pomiędzy Rosją a Italią w XviıI wieku ${ }^{17}$. O dyplomatycznych kontredansach włoskiego zakonnika pisał również autor niniejszego tekstu ${ }^{18}$, także w wersji hiszpańskiej w Madrycie ${ }^{19}$. Ten właśnie środkowy etap życia Arcellego, związany z aktywnością dyplomatyczną, z misjami w Rosji i Polsce, jest więc najlepiej rozpoznany. Niewiele wiadomo natomiast na temat dzieciństwa, młodości oraz jesieni życia teatyna. Spróbujmy więc ustalić podstawowe fakty z jego biografii.

Rodzina Arcellich wywodziła się z Piacenzy, a jej pierwszych reprezentantów należy szukać w XII wieku. Należeli do elity społecznej i politycznej tej części Italii. Wśród jej przedstawicieli spotykamy kupców, bankierów, wojskowych i polityków. Wspomniana już Maria d’Amato twierdzi, że Francesco był synem, zmarłego w 1727 roku, hrabiego Ottavio ${ }^{20}$. Z tym poglądem polemizują genealodzy, autorzy Złotej księgi szlachty śródziemnomorskiej (Libro d’oro della nobilità mediterranea). Ich zdaniem Francesco urodził się w rodzinie Carlo Arcellego di Vajrasco (1669-1738) oraz Klary Torricelli (zm. 1734) ${ }^{21}$. Pozostawiając te kwestie do wyjaśnienia biografom, przyjrzyjmy się głównym płaszczyznom aktywności naszego bohatera w wieku już dojrzałym.

\section{Arcelli zakonnik}

Zapewne już jako młody człowiek zdecydował się na drogę zakonną. Na podstawie aktualnego stanu badań trudno jednak stwierdzić, jakimi intencjami

${ }^{16}$ Dziękuję bardzo pani Natalii Terekhovej za cenne informacje dotyczące stanu badań na temat relacji rosyjsko-włoskich $\mathrm{w}$ XVıII wieku.

${ }_{17}$ Zob. N. Terekhova, Н. Г. Терехоbа, Падре Ариеллииегоневыполнимаямиссия, [w:] РоссиаиИталиа Вьп. 6: Италианцььв РоссииотДревнейРуссидонаших дней, Ленанд 2015; Тra macro e micro. Le lettere inedite da Parma e Gustalla trovate negli archivi di Mosca e le nuove prospettive nella storia delle relazioni italo-ruse nel XVII secolo, referat wygłoszony podczas konferencji „Settecento oggi: studi e ricerche in corso”, Marina di Massa - Villaggio Torre Marina, 28-30.05.2015.

18 Zob. C. Taracha, Szpiedzy i dyplomaci. Wywiad hiszpański w XVIII wieku, Lublin 2005.

19 Zob. C. Taracha, Ojos y oídos de la Monarquía Borbónica. La organización del espionaje y la información secreta durante el siglo XVIII, Madrid 2011.

${ }_{20}$ Zob. M. D’Amato, Un teatino diplonatico del secolo XVIII (Francesco Arcelli). Contributo a la storia delle relazioni tra l'Italia e la Russia. Con appendice di documenti inediti, Napoli 1922.

${ }^{21}$ Zob. http://www.genmarenostrum.com/pagine-lettere/letteraa/Arcelli/A R CELLI\%2O del\%2oCastellaro\%2oArcelli.htm (21.10.2016). 
kierował się Francesco, wybierając zgromadzenie kleryków regularnych, zwanych potocznie teatynami (il. 1).

Przypomnijmy, że zakon teatynów (Ordo Clericorum Regularium vulgo Theatinorum), oparty na regule św. Augustyna, powstał na terenie Italii (Chieti) w 1524 roku, a jego założycielami byli św. Kajetan z Thieny ${ }^{22}$ oraz biskup Giovanni Pietro Caraffa (późniejszy papież Paweł IV) ${ }^{23}$. Teatyni (il. 2) odwoływali się do czasów apostolskich jako drogi uświęcania kapłanów oraz odnowy moralnej Kościoła. Wyróżniali się swoją skromnością materialną, akcentowaniem potrzeby zaufania opatrzności Bożej oraz szczególną dbałością o kult i jakość liturgii. W związku $\mathrm{z}$ tym ich głównym zadaniem było kształcenie i formacja przyszłych księży.

Pierwsze domy zgromadzenia poza Italią powstały na terenie Hiszpanii (Madryt, Saragossa, Barcelona, Alcalá de Henares) za sprawą ojca Plácido Frangipane Mirto, spowiednika polskiego ambasadora w Madrycie Adama Makowskiego ${ }^{24}$. Następnie teatyni założyli swoje domy w Portugalii, w Cesarstwie (Praga, Salzburg) oraz w Polsce (Warszawa, Lwów).

Nie dysponujemy niestety informacjami dotyczącymi zakonnej formacji oraz posługi Arcellego w zgromadzeniu. Wiadomo natomiast, z korespondencji księcia de Liria, że przed 1731 rokiem został on przełożonym jednego $\mathrm{z}$ konwentów. Jego przynależność do kleryków regularnych i znajomości z polskimi teatynami z Warszawy ułatwiały mu z pewnością kontakty z elitami politycznymi Rzeczypospolitej. Przypomnijmy, że w 1737 roku teatyni założyli w stolicy Polski nowoczesną i ekskluzywną szkołę dla młodzieży szlacheckiej (Collegium Varsoviense) ${ }^{25}$, w której większość nauczycieli pochodziła $\mathrm{z}$ Włoch ${ }^{26}$. Jednym z najbardziej znanych był Antoni Maria Portalupi $(1713-1791)^{27}$, pedagog w warszawskim Kolegium Teatynów, nadworny kapelan Augusta III, a następnie bliski współpracownik

${ }^{22}$ Kajetan $z$ Themy (1480-1547), urzędnik papieski, założyciel zakonu teatynów, duszpasterz ubogich.

${ }^{23}$ Giovani Pietro Carafa (1476-1559), współzałożyciel zakonu teatynów, kardynał, papież Paweł IV (1555-1559).

${ }^{24}$ Zob. R. Skowron, Dyplomaci polscy w Hiszpanii w XVI i XVII wieku, Kraków 1997.

${ }_{25}$ Zob. S. Suchodolski, D. Ostapowicz, Obalanie mitów i stereotypów. Od Jana III Sobieskiego do Tadeusza Kościuszki, Warszawa 2008, s. 88.

${ }_{26}$ Zob. R. Pelczar, Teatyni w Warszawie w XVIII w., „Nasza Przeszłość” 108 (2007), s. 147-181; R. Pelczar, Teatr Collegium Nobilium teatynów w Warszawie $w$ XVIII w. i jego rola kulturotwórcza, „Pamiętnik Teatralny” 55 (2007) z. 1-2, s. 41-52.

${ }^{27}$ Inny znany teatyn to wybitny architekt Gaetano Chiaveri (1689-1770), włoski architekt, twórca katedry w Dreźnie. W latach 1717-1727 pracował w Petersburgu dla Piotra I, a następnie, w latach 30. XVIII wieku, przebywał w Warszawie. 
Stanisława Augusta Poniatowskiego, wychowanka Kolegium (absolwentami szkoły byli również Kazimierz Pułaski, Michał Bonawentura Potulicki, Michał Jerzy Poniatowski i Karol Maurycy Lelewel, ojciec Joachima).

\section{Arcelli dyplomata}

Przejdźmy więc do tego okresu w życiu Arcellego, kiedy wszedł w świat wielkiej polityki i zdecydował się na służbę o charakterze świeckim. Około 1717 roku włoski zakonnik wkroczył na drogę służby dyplomatycznej, najpierw reprezentował księcia Parmy, a następnie króla Hiszpanii. Celem jego pierwszej misji stały się negocjacje w sprawie małżeństwa pomiędzy infantem hiszpańskim Don Carlosem a młodszą córką cara Piotra I Wielkiego. W drodze do Rosji Arcelli zatrzymał się na pewien czas w Warszawie. Tu zawarł cenne znajomości z przedstawicielami polskich elit politycznych oraz z rosyjskim ambasadorem w Polsce Grigorijem Dołgorukim ${ }^{28}$. Kiedy Dołgoruki został odwołany z Warszawy, Arcelli wyjechał razem z nim do Moskwy, gdzie podjął zlecone mu rokowania w sprawie małżeństwa oraz ewentualnego sojuszu rosyjsko-hiszpańskiego ${ }^{29}$.

Po zakończeniu misji w Rosji wrócił do Polski. Tu otrzymał kolejne zlecenie, tym razem $\mathrm{w}$ imieniu dworu hiszpańskiego. Jego misja wiązała się $\mathrm{z}$ dwoma czynnikami mającymi decydujący wpływ na ówczesną sytuację międzynarodową i politykę zagraniczną Hiszpanii. Pierwszy z nich to plany królowej Hiszpanii, ambitnej Włoszki Elżbiety Farnese, drugiej żony Filipa v. Zdając sobie sprawę, że tron hiszpański przypadnie synom króla z pierwszego małżeństwa ${ }^{30}$, Elżbieta poszukiwała możliwości osadzenia swoich synów na innych tronach w Europie. W grę wchodziła przede wszystkim Italia (Neapol, Parma), ale nie odrzucano także innych pojawiających się okazji, a taką była spodziewana nowa elekcja w Polsce. Druga okoliczność to rozwój wydarzeń w Rzeczypospolitej i w tej części Europy, gdzie kształtowały się nowe mocarstwa europejskie (Rosja, Prusy, Cesarstwo). Choroba Augusta II i zbliżająca się elekcja nowego władcy mobilizowały państwa

${ }^{28}$ Grigorij Dołgoruki (1656-1723), rosyjski wojskowy, dyplomata i polityk, w latach 1715-1721 ambasador w Polsce.

29 Zob. La correspondencia diplomática entre los duques de Parma y sus agentes o embajadores en la corte de Madrid durante los siglos XVI, XVII y XVIII, ed. C. Pérez Bustamante, Madrid 1934, s. 19.

30 Z pierwszego małżeństwa z Marią Luizą Sabaudzką Filip v miał synów Ferdynanda i Filipa, którzy mieli pierwszeństwo do korony hiszpańskiej. 
europejskie do poszukiwania własnych korzyści z okazji zmiany na polskim tronie. O część tego tortu chciała zawalczyć również burbońska Hiszpania.

Wybór Arcellego do tej właśnie trudnej misji wiązał się, jak przypuszczam, przede wszystkim z poparciem księcia de Liria ${ }^{31}$, wpływowego dyplomaty hiszpańskiego, który zetknął się z włoskim teatynem w Rosji. Liria, przeniesiony z Petersburga do Wiednia, wystawił zakonnikowi, jeśli można tak to ująć, znakomite referencje, mając nadzieję, że będzie on skutecznym narzędziem realizacji planu osadzenia na tronie polskim hiszpańskiego infanta. Pozwolę sobie zacytować fragmenty jego listu do przełożonych w Madrycie:

Dla realizacji przedsięwzięć, które proponuję, konieczne jest abyśmy mieli tu jakiegoś emisariusza, który nie tylko wykona to, co zostanie mu zlecone, ale będzie również szczegółowo informował o rozwoju sytuacji w tym królestwie. W związku z tym pomyślałem o pewnym człowieku, który tutaj właśnie przebywa, ma dużą wiedzę o tym kraju, jest wszystkim znany, posiada najwyższe kompetencje, i będzie mało kosztował naszego króla. Nazywa się on Francesco Arcelli, jest zakonnikiem teatynem, ostatnio został przełożonym swego konwentu [...]. Z pochodzenia parmeńczyk, jest bardzo gorliwy w służbie [naszego] króla. Za roczną pensję 400 doblonów, jaką się mu zaoferuje, będzie mógł dobrze służyć, wypełniając zadania, które proponuję. Jego duchowny stan oraz długi czas pobytu w tym miejscu, to okoliczności, które sprawiają, że jest on mniej podejrzany niż ktoś inny przysłany bezpośrednio [z Hiszpanii]. Nie mówi po hiszpańsku, ale przecież na naszym dworze nie brakuje osób mogących prowadzić z nim korespondencję w języku włoskim. Jeżeli Jego Wysokość uzna, że jestem godny tej funkcji, mogę się podjąć tego zadania [il. 3].

W oparciu o tego rodzaju rekomendacje markiz de la Paz, minister odpowiedzialny za politykę zagraniczną, powierzył Arcellemu delikatną misję w Polsce, wyznaczając roczną pensję w wysokości 400 dublonów ${ }^{32}$. Jej podstawowe cele zostały określone w instrukcji z 30 kwietnia 1731 roku, której edycja zamieszczona jest w aneksie. Wynika z niej, że zakonnik miał rozpoznać nastroje panujące w Polsce, zwłaszcza zaś poglądy liderów głównych sił politycznych w kwestii przyszłej elekcji, aby następnie dyskretnie lansować kandydaturę hiszpańskiego infanta.

${ }^{31}$ Jacobo Francisco Fitz-James Stuart, książę de Liria (1696-1738), wojskowy i dyplomata pochodzenia irlandzkiego na służbie Hiszpanii, w latach 1727-1730 ambasador w Rosji. Zob. D. Ozanam, Les diplomates espagnols $d u$ XVIII siècle..., dz. cyt., s. 258-259.

${ }^{32}$ Zob. Archivo General de Simancas (dalej: AGs), Estado, Liria do Paza, Wiedeń, 5.12.1731. 
Ponieważ Arcelli nie znał języka hiszpańskiego, nie posiadał również klucza kodowego do bezpośredniej korespondencji z dworem w Madrycie, Liria zalecił $\mathrm{mu}$, aby pisał on swe raporty po włosku oraz posługiwał się matrycą przygotowaną przez księcia. Po odszyfrowaniu listów Liria kierował je z Wiednia do Madrytu, opatrując własnymi komentarzami dotyczącymi wartości informacji przekazywanych przez teatyna (il. 4,5$)^{33}$.

Początkowo Arcelli starał się nie ujawniać charakteru swego pobytu w Polsce. Zgodnie z zaleceniami instrukcji obserwował rozwój wydarzeń w Rzeczypospolitej, sondował opinie wpływowych polityków. Informował o niechęci znaczącej części społeczeństwa do dynastii saskiej. Równocześnie starał się dyskretnie wskazywać pewne rozwiązania i zachowania podczas zbliżającej się elekcji. W jednym $z$ listów pisał: „jedyne, co czynię, to sugerowanie zaufanym osobom konieczności wyboru na króla Polski kandydata pochodzącego z jak najdalszych stron" ${ }^{34}$. Sytuacja zmieniła się diametralnie, gdy 1 lutego 1733 roku zmarł August II i rozpoczęła się „kampania wyborcza”. Arcelli postanowił wystąpić oficjalnie, poprosił więc w szyfrowanym liście o stosowne upoważnienie. Jego propozycja spotkała się ze zrozumieniem hiszpańskich władz. W Madrycie przygotowano dla niego plenipotencje i kredencjały do Rzeczypospolitej oraz prymasa Polski, które zostały wysłane przez kuriera nadzwyczajnego do Wiednia, a stąd po zaszyfrowaniu do Warszawy. Zalecono mu jednak, aby skorzystał z tych instrumentów i upublicznił je dopiero wtedy, gdy będzie całkowicie przekonany o powodzeniu swej misji ${ }^{35}$.

Zajrzyjmy więc do przekazanych Arcellemu z zachowaniem największych środków ostrożności ${ }^{36}$ materiałów. Co zawierały sygnowane przez króla Filipa v oraz ministra José Patiño dyspozycje? Najważniejsza z nich to podpisana 9 marca 1731 roku nominacja teatyna na stanowisko ministra pełnomocnego w Polsce. W liście do prymasa Polski Teodora Andrzeja Potockiego ${ }^{37}$ Filip v pisał: „Pragnąc wyrazić w najlepszy możliwy sposób moją szczególną skłonność do utrzymywania i zacieśniania szczerych więzi z tym państwem, uznałem za stosowne mianować ojca

33 Zob. AGs, Estado, 6541, Liria do Arcellego, Wiedeń, 5.08.1731.

34 AGs, Estado, 6541, Liria do Paza, Praga, 12.08.1732: yo no hago más que representar a mis confidentes la necesidad de hacer rey de Polonia de los más lejanos.

${ }_{35}$ Zob. Ags, Estado, 6541, Markiz de la Paz do Josepha de Viaba y Eguiluz, Sevilla, 9.03.1733.

${ }^{36}$ Joseph de Viana y Eguiluz przesłał dokumenty przez kuriera nadzwyczajnego, ale w taki sposób, że kurier nie znał ani nadawcy, ani ostatecznego odbiorcy przesyłki. Zob. AGs, Estado, 6541, Joseph de Viana y Eguiluz do Patiño, Wiedeń, 1.04.1733.

37 Teodor Andrzej Potocki (1664-1738), biskup chełmiński i warmiński, prymas Polski w latach 1722-1738; sekretarz królewski. W 1733 roku podpisał elekcję Stanisława Leszczyńskiego. 
Francesco Arcellego moim ministrem pełnomocnym na jego terenie" ${ }^{38}$. Podobną treść miało pismo skierowane do stanów Rzeczypospolitej (il. 6).

Nominacja dawała włoskiemu teatynowi pełnię kompetencji w zakresie reprezentowania króla Hiszpanii w Rzeczypospolitej, prowadzenia rozmów z prymasem (interreksem), ministrami, senatorami, posłami, podpisywania w imieniu króla Hiszpanii traktatów i układów. W ten sposób włoski zakonnik miał stać się najwyższym przedstawicielem dyplomatycznym monarchii katolickiej w tej części Europy. Możemy wyobrazić sobie, jakie wrażenie wywarła ta decyzja na nim samym. Stając się oficjalnym przedstawicielem dyplomatycznym potężnego państwa, mógł kreślić wielkie plany na przyszłość. Jego status w porównaniu do wiosny 1731 roku, kiedy to został nieoficjalnym wysłannikiem Madrytu, wzrósł w sposób spektakularny. I tu, jak się wydaje, tkwi przyczyna jego niepowodzenia. Arcelli popełnił zasadniczy błąd, nie zapanował nad emocjami, przestał myśleć i działać racjonalnie. Abstrahując od kierunku rozwoju wydarzeń w Polsce i na arenie międzynarodowej, podejmował działania sprzeczne z oczekiwaniami swych mocodawców.

Przez kilka kolejnych miesięcy w 1733 roku informował o sytuacji panującej w Warszawie oraz o swoich poczynaniach w interesie Hiszpanii. Dla przykładu, w tydzień po śmierci Augusta II, opisywał obrady Rady Senatu oraz Izby Poselskiej pod kierunkiem prymasa. Wskazywał, że najpoważniejszymi kandydatami do tronu są syn zmarłego monarchy August oraz Stanisław Leszczyński, ale swoje ambicje mają również przedstawiciele rodów magnackich: Potoccy, Lubomirscy i Czartoryscy. Chętnie podkreślał swoje wysiłki w promowaniu kandydatury infanta hiszpańskiego: „ed io, in una compagnia dei mei confidenti, ho suggerito un principe di Spagna; pero solamente per modo di discurso, e con delicadezza" ${ }^{39}$. Po koniec maja 1733 roku przekazał informację, że sejm konwokacyjny podjął decyzję o wykluczeniu cudzoziemców pretendentów do tronu polskiego: „Sabbato passato li 23 del corrente su ultima sessione de la dieta che duro tutta la notte alle 5 hore della Domenica sequente, e si fini con gran strepito et quale ammirazione, havendo tutti i senatori, vescovi, palatyni e deputati solennemente giurato di non eleggere pero loro re lacuno principe forestiere" ${ }^{\prime 0}$. Arcelli pisał o wielkim wrażeniu, jakie ta decyzja wywarła na przedstawicielach obcych dworów, a także na Polakach stronnikach dynastii saskiej. Wspominał też, że przed terminem elekcji na teren Rzeczypospolitej wkroczą wojska rosyj-

\footnotetext{
${ }^{8}$ AGs, Estado, 6541, Sevilla, 9.03.1733.

39 AGs, Estado, 6541, list Arcellego, Warszawa, 7.02.1733.

40 AGs, Estado, 6541, list Arcellego, Warszawa, 26.05.1733.
} 
skie. Jego zdaniem decyzja polskiego parlamentu w żaden sposób nie naruszała jednak prestiżu króla Hiszpanii, ponieważ Arcelii nie zdradził prawdziwych celów swej misji w Warszawie ${ }^{41}$. W tym właśnie okresie, pomiędzy głośną decyzją sejmu a wkroczeniem wojsk rosyjskich (sierpień), Arcelli ujawnił się całkowicie i oświadczył publicznie, że został mianowany ministrem pełnomocnym Filipa v w Polsce. Informacja ta wywołała poważne zaniepokojenie w Madrycie, dokąd dotarła za pośrednictwem Josepha de Viana y Eguiluz ${ }^{42}$, sekretarza hiszpańskiej ambasady w Wiedniu ${ }^{43}$. Dlaczego Arcelli zdecydował się na ten krok? On sam tłumaczył się chorobą prymasa Potockiego i swoimi obawami, że interreks umrze przed terminem elekcji. Było to oczywiście sprytne zagranie, gdyż w razie zgonu prymasa jego list uwierzytelniający tracił ważność i uniemożliwiał podejmowanie oficjalnych działań dyplomatycznych.

Wydaje się jednak, że w grę wchodziły również inne czynniki. Przedstawiając listy uwierzytelniające, teatyn miał nadzieję na trwałe usadowienie się w stolicy Polski w charakterze dyplomatycznego przedstawiciela Hiszpanii, a z tym oczywiście wiązały się określone przywileje i wpływy oraz finansowa stabilizacja.

Tymczasem jednak rozwój sytuacji międzynarodowej uniemożliwił realizację planów Elżbiety Farnese w Polsce. Koniec dyplomatycznej przygody i służby dla hiszpańskich Burbonów nie był dla Arcellego już tak przyjemny, jak jej początek i późniejsze wydarzenia. Zmieniły się okoliczności, a jego działalność w Polsce nie przyniosła spodziewanych rezultatów. Włoski zakonnik nie zdołał się wykazać żadnymi sukcesami. Zdając sobie sprawę, że jest coraz mniej przydatny mocodawcom z Hiszpanii, postanowił zadbać o własne interesy. Długo nie przyjmował do wiadomości faktu odwołania $\mathrm{z}$ warszawskiej placówki, a kiedy okazało się, że decyzja Madrytu jest ostateczna, postanowił zrobić użytek z powierzonych sobie sekretnych dokumentów, zwłaszcza listów uwierzytelniających oraz matrycy szyfrowej. Miały mu one posłużyć jako swego rodzaju polisa przetargowa albo ubezpieczeniowa. Mimo usilnych nalegań z Madrytu, Arcelli nie chciał zwrócić do ministerstwa tajnych dokumentów. Delikatną misję ich wydobycia z rąk

${ }^{41}$ Zob. Ags, Estado, 6541, list Arcellego, Warszawa, 26.05.1733.

${ }^{42}$ Joseph de Viana y Eguiluz (ok. 1695-1750), hiszpański urzędnik i dyplomata niższego szczebla, w latach 1726-1734 sekretarz ambasady w Wiedniu. Zob. D. Ozanam, Les diplomates espagnols $d u$ XVIII siècle..., dz. cyt., s. 466-467.

${ }^{43}$ Zob. AGs, Estado, 6541, Joseph de Viana y Eguiluz do Patiño, Wiedeń, 9.09.1733: En la de 15 venía ya insinuando aquel religioso, que havía juzgado a propósito, presentar la credencial al primado de Polonia, pero no da para ello más razón que la de hallarse poco bueno el mismo primado, y que si llegase a faltar, de nada le serviría después la credencial. 
intryganta powierzono hrabiemu de Montijo $^{44}$, który pełnił wówczas funkcję ambasadora Hiszpanii w Londynie ${ }^{45}$.

Doświadczony dyplomata postanowił przede wszystkim rozegrać batalię z dala od Polski, gdzie w przypadku niepowodzenia przedsięwzięcia cała sprawa mogła doprowadzić do licznych komplikacji. Kiedy w lipcu 1735 roku kończył swą misję w Londynie, udał się do Hanoweru, który w owym czasie był związany pod względem politycznym i dynastycznym z Wielką Brytanią ${ }^{46}$. Tu właśnie nakazał stawić się Arcellemu ${ }^{47}$. W sierpniu 1735 roku spotkał się z zakonnikiem i starał się nakłonić go do zwrotu tajnych dokumentów. Pod wpływem perswazji teatyn zwrócił instrukcję z 30 kwietnia 1731 roku, kopie kredencjałów do prymasa i stanów Rzeczpospolitej oraz kilka listów ${ }^{48}$. Pozostałe dokumenty zatrzymał jednak dla siebie. W tej sytuacji Montijo przekazał mu 300 pesos ${ }^{49}$, żądając, aby wyjechał do Hamburga i czekał na dalsze polecenia. Zalecał również, aby nie spotykał się z obcymi dyplomatami akredytowanymi w tym mieście. Zakonnik wystąpił jednak z nowymi żądaniami. Domagał się mianowicie, aby król Hiszpanii mianował go swoim przedstawicielem dyplomatycznym (chargé d’affaires) w Hamburgu. Montijo, czyniąc pewne obietnice w tym zakresie, zdołał odzyskać kolejne materiały, w tym listy księcia de Liria oraz Josepha Eguiluza. Nie zdołał jednak przejąć klucza szyfrowego. Arcelli oświadczył, że spalił go, a poza tym stanowił on własność księcia Parmy, a nie rządu hiszpańskiego. Czy mówił prawdę? Nie wiadomo. Gdyby jednak Arcelli sprzedał szyfr bądź przekazał go na innej zasadzie jednemu z obcych dyplomatów lub agentów, istotne tajemnice hiszpańskiego rządu mogłyby trafić do wiadomości obcych. Wiązałoby się to również $\mathrm{z}$ innymi problemami, np. narażeniem na niebezpieczeństwo pracujących dla króla katolickiego informatorów, zwłaszcza zaś poddanych innych władców.

${ }^{44}$ Cristobál Gregorio Portocarrero y Funes de Villalpando, htabia de Montijo (1692-1761), hiszpański dyplomata, w latach 1731-1735 ambasador w Wielkiej Brytanii. Zob. D. Ozanam, Les diplomates espagnols $d u$ XVIII siecle..., dz. cyt., s. 401-402.

45 Zob. Ags, Estado, 6541, Patiño do Montijo, San Ildefonso, 19.09.1735: podrá Vuestra Excelencia sacarle con maña los poderes, instrucciones y demás papeles con que se halla.

${ }^{46}$ Zob. D. Ozanam, Les diplomates espagnols du XVIII siècle..., dz. cyt., s. 401.

47 Zob. Ags, Estado, 6541, Montijo do Patiño, Hanover, 30.08.1735.

48 Zob. Ags, Estado, 6541, Montijo do Patiño, Hanover, 30.08.1735.

49 Arcelli pokwitował odbiór tych pieniędzy własnoręcznym podpisem: AGs, Estado, 6541: Recibo de D. Pedro Tyrry, por orden del Exmo. Sr. conde del Montijo, embajador extraordinario de Su Magestad Católica la cantidad de trescientos pesos, que hace florines de Alemania cuatrocientos y cincuenta, cuya cantidad es para pagar mis gasto en esta ciudad y pasar a Hamburgo y por su verdad firmé éste en Hanover en 29 de agosto de 1735. 
Jakie były dalsze losy Francesco Arcellego? Z materiałów znajdujących się w Archivo General de Simancas wynika, że przez pewien czas pozostawał on w Hamburgu. $Z$ tego miejsca słał listy do hrabiego del Montijo, informując go o różnych wydarzeniach, ofiarując swe usługi dla Hiszpanii i prosząc o wstawiennictwo u króla. Dostarczane przez niego wiadomości były jednak przysłowiową tajemnicą poliszynela i nie miały szczególnej wartości dla władz w Madrycie. W styczniu 1738 roku na przykład donosił o małżeństwie zawartym przez Karola, syna króla Hiszpanii, z córką Augusta II Marią Amalią ${ }^{50}$, co można uznać wręcz za niepoważne ${ }^{51}$. Pomysłowy zakonnik miał jednak inne źródło dochodu. Sprzedawał stopniowo hrabiemu del Montijo tajne dokumenty będące własnością rządu hiszpańskiego, które ten wykupywał w ramach tzw. wydatków nadzwyczajnych ambasady ${ }^{52}$. Jak długo trwał ten proceder, tego, przynajmniej na razie, nie wiadomo.

\section{Podsumowanie}

Na zakończenie niniejszego tekstu warto powrócić do postawionych na początku pytań o konsekwencje zaangażowania osób duchownych w sprawy świeckie, polityczne i dyplomatyczne. Można przypuszczać, że jako zakonnik składający śluby posłuszeństwa otrzymał on jakieś (pisemne czy ustne) zezwolenie swoich przełożonych na tego rodzaju działalność. Nie był rzecz jasna wyjątkiem. Wielu zakonników w XVIII-wiecznej Europie podejmowało służbę na rzecz władców, państw, wpływowych polityków, ministrów, dyplomatów, wchodząc w obszar wielkiej czy lokalnej polityki, konfliktu interesów, walki informacyjnej. Niektórzy z nich osiągali szczyty władzy politycznej, pełniąc ważne funkcje państwowe. Inni pracowali w służbach zagranicznych. W przypadku Arcellego mamy do czynienia $\mathrm{z}$ karierą średniego formatu. W pierwszej fazie zapowiadała się ona bardzo pomyślnie. Teatyn wszedł na służbę niewielkiej Parmy, ale następnym jego mocodawcą był potężny król Hiszpanii. Spędził wiele lat w Europie Środkowej i Wschodniej, poznał dobrze tamtejsze realia polityczne, poznał elity politycznej i społeczne, zawarł cenne znajomości, zdobył pewien autorytet.

50 9 maja 1738 roku w Dreźnie zawarty został ślub (per procura) pomiędzy królem Neapolu Karolem a Marią Amalią.

${ }_{51}$ Zob. Ags, Estado, 6541,Arcelli do Montijo, Hamburg, 10.01.1738.

${ }_{52}$ Zob. AGs, Estado, Montijo do Sebastiána de la Cuadra, Madryt, 23.02.1738. 
Misja w Polsce zapowiadała się jako zwieńczenie jego kariery i znaczący awans w hierarchii dyplomatycznej. Stało się jednak inaczej. Sytuacja międzynarodowa, rozwój wydarzeń w Rzeczypospolitej, ale również jego własne błędy spowodowały, że stracił całkowicie zaufanie swych mocodawców. A jego upadek był znaczny. Z pozycji oficjalnego przedstawiciela monarchii katolickiej, kierownika placówki dyplomatycznej, stał się szantażystą, a następnie tolerowanym z konieczności uciążliwym źródłem bezwartościowych informacji.

Przypadki takie jak ten stanowiły istotny argument za stopniowym odsuwaniem cudzoziemców i duchownych od służby dyplomatycznej w Hiszpanii, za jej „nacjonalizacją” i laicyzacją. Te założenia stały się priorytetem polityki personalnej hrabiego de Floridablanca, który w latach 1776-1792 kierował hiszpańską dyplomacją.

Kwestia hiszpańskiego kandydata do korony polskiej wracała jeszcze w XVIII wieku. W latach 50. na przykład tajne sondażowe rozmowy w tej sprawie prowadzili ambasador Ferdynanda vi w Paryżu Jaime Massones de Lima ${ }^{53}$ oraz książę Jan Kajetan Jabłonowski ${ }^{54}$.

53 Jaime Massones de Lima y Sotomayor (1696-1778), hiszpański wojskowy i dyplomata, w latach 1752-1761 ambasador w Paryżu. Zob. D. Ozanam, Les diplomates espagnols du XVIII siècle..., dz. cyt., s. $346-347$.

${ }^{54}$ Zob. Archivo Histórico Nacional, Estado, 6509, Massones de Lima do Walla, 13.09.1755 i odpowiedź Walla z 9.10.1755. 
INSTRUKCJA DLA OJCA FRANCESCO ARCELLEGO, 1731 ROK

\author{
Archivo General de Simancas, Estado, 6541
}

Najwielebniejszy Ojcze. Pierwszym celem oraz troską, jaką Wasza Wielebność powinna mieć na uwadze, będzie zapoznanie się z najważniejszymi magnatami polskimi oraz podjęcie próby wybadania i upewnienia się, którzy polscy panowie myślą pretendować do korony i jakie środki mogą być znalezione, aby zrealizować ich zamiary.

Podobnie Wasza Wielebność powinien zbadać i postarać się odkryć, jacy obcy książęta myślą o wstąpieniu na ów tron; którzy władcy ich popierają i jakie konkretne negocjacje prowadzą w tym celu.

Zapoznawszy się już z głównymi polskimi magnatami, postara się Wasza Wielebność podejmować od czasu do czasu temat przyszłej sukcesji; sugerować, że jeżeli będzie się chciało wybrać Polaka, elekcja ta zostanie narażona na liczne trudności oraz niepokoje; i że najbardziej właściwym byłoby poszukanie jakiegoś księcia cudzoziemca, którego siły nie mogą rzucić żadnego cienia na Rzeczpospolitą, jak i naród.

Po założeniu tego pierwszego fundamentu, Wasza Wielebność zręcznie i bez emocji rozważy zalety poszczególnych książąt europejskich, aby delikatnie wskazać na Najjaśniejszego Infanta Don Filipa, uwypuklając jego wysokie urodzenie; na to, co obiecuje ze względu na swe niezrównane zalety; i przede wszystkim, że Hiszpania jest tak odległa od Polski, iż Rzeczpospolita nigdy nie będzie musiała obawiać się, że może ona posłużyć się swymi siłami, aby zniszczyć fundamentalne prawa tego królestwa. Wasza Wielebność da do zrozumienia, że jego młody wiek sprawi, że bez przeszkód przyjmie wszelkie krajowe zwyczaje i utożsami się z nim do tego stopnia, iż będzie niczym prawdziwy Polak.

Nie poczyni jednak Wasza Wielebność tych deklaracji bez dobrego rozeznania nastrojów oraz ludzi bezstronnych, którzy mają na względzie jedynie dobro ojczyzny.

Będzie Wasza Wielebność postępować z ostrożnością, zwłaszcza w stosunku do zwolenników obecnego króla, rodzin Potockich, Czartoryskich, Poniatowskich, Wiśniowieckich i [słowo nieczytelne - przyp. C. T.]. Postara się pozyskać wolę i przyjaźń biskupa płockiego Załuskiego, pamiętając jednak, aby wystrzegać się otwartej rozmowy z nim aż do czasu, gdy Wasza Wielebność uzna, że może to uczynić z całkowitym bezpieczeństwem.

Wasza Wielebność uczyni wszystko, co możliwe, aby dokładnie rozpoznać stronnictwo, które posiada król Stanisław, jak również partię francuską oraz jakie są zamiary cesarza, carycy i króla Prus. 
Poinformuje Wasza Wielebność, jaka suma pieniędzy będzie potrzebna, aby zrealizować projektowane przez nas zamierzenia, kiedy dojdzie do wakowania tronu oraz, których wysoko postawionych ludzi możemy być pewni. Kiedy tylko zawakuje tron, Wasza Wielebność powiadomi natychmiast królewskiego ministra, który rezyduje w Wiedniu, aby natychmiast wprowadzić w czyn polecenia, które z uprzedzeniem będzie miał w tym celu.

Od tej pory i w przyszłości Wasza Wielebność poinformuje bardzo szczegółowo dla wiedzy króla naszego pana o wszystkim, co się wydarzy, a szczególnie o wszelkich poczynaniach cudzoziemskich ministrów. Jedną z podstawowych trosk Waszej Wielebności będzie również to, aby nie dać się nikomu rozpoznać jako hiszpański emisariusz czy agent. Będzie Wasza Wielebność przestrzegać najgłębszego sekretu we wszystkich swych działaniach. Niech Bóg raczy zachować Waszą Wielebność wiele lat, czego życzę. Sewilla, 30 kwietnia 1731. [podpis] Markiz de la Paz.

Tłumaczenie Cezary Taracha

\section{Bibliografia}

Archivo General de Simancas, Estado, 6541:

Liria do Arcellego, Wiedeń, 5.08.1731.

Liria do Paza, Praga, 12.08.1732.

Markiz de la Paz do Josepha de Viaba y Eguiluz, Sevilla, 9.03.1733.

Joseph de Viana y Eguiluz do Patiño, Wiedeń, 1.04.1733.

Sevilla, 9.03.1733.

List Arcellego, Warszawa, 7.02.1733.

List Arcellego, Warszawa, 26.05.1733.

Joseph de Viana y Eguiluz do Patiño, Wiedeń, 9.09.1733.

Patiño do Montijo, San Ildefonso, 19.09.1735.

Montijo do Patiño, Hanover, 30.08.1735.

Montijo do Patiño, Hanover, 30.08.1735.

Arcelli do Montijo, Hamburg, 10.01.1738.

Archivo General de Simancas, Estado, Montijo do Sebastiána de la Cuadra, Madryt, 23.02.1738.

Caro Baroja J., Pan inkwizytor, tłum. i wstęp C. Taracha, Lublin 2000.

d'Amato M., Un teatino diplomatico del secolo XVIII. Contributto alla storia delle relazioni tra Italia e la Russia, Napoli 1922. 
La correspondencia diplomática entre los duques de Parma y sus agentes o embajadores en la corte de Madrid durante los siglos XVI, XVII y XVIII, ed. C. Pérez Bustamante, Madrid 1934.

Ozanam D., Les diplomates espagnols du XVIII siècle. Introduction et répertoire biographique (1700-1808), Madrid-Bordeaux 1989.

Pelczar R., Teatyni w Warszawie w XVIII w., „Nasza Przeszłość” 108 (2007), s. 147-181.

Pelczar R., Teatr Collegium Nobilium teatynów w Warszawie w XVIII w. i jego rola kulturotwórcza, „Pamiętnik Teatralny” 55 (2007) z. 1-2, s. 41-52.

Pinedo I., Platzgummer H., Niedhard (Nithard), Johann Eberhard, [w:] Diccionario histórico de la Compañía de Jesús, vol. 3, ed. Ch. E. O’Neill, J. M. Domínguez, Roma-Madrid, s. 2818-2819.

Rocca N., Un diplomatico piacentino Alla corte di Pietro il Grande, „Liberta”, 31.01.1967, s. 3-21. Rodríguez Polo M., El duque de Liria a su paso por Polonia, „Eslavística Complutense” 8 (2008), s. 207-231.

Skowron R., Dyplomaci polscy w Hiszpanii w XVI i XVII wieku, Kraków 1997.

Suchodolski S., Ostapowicz D., Obalanie mitów i stereotypów. Od Jana III Sobieskiego do Tadeusza Kościuszki, Warszawa 2008.

\section{Abstrakt}

Stulecie XVIII to czas trudnych wyzwań tak dla życia zakonnego w ogóle, jak i dla konkretnych zgromadzeń. Przypomnijmy takie wydarzenia, jak likwidacja redukcji paragwajskich, wypędzenie jezuitów z Portugalii i Hiszpanii, rozwiązanie Towarzystwa Jezusowego, likwidacja setek domów zakonnych w ramach reform józefińskich czy okrutne represje wobec duchowieństwa z czasów rewolucji francuskiej. Mimo prób kwestionowania obecności zakonów w przestrzeni publicznej odgrywały one nadal istotną rolę w wielu obszarach życia społecznego, w świecie kultury i edukacji. Oprócz posługi właściwej zakonnym charyzmatom spotykamy zakonników na królewskich dworach, pełniących ważne funkcje w administracji państwowej, w dyplomacji, na uniwersytetach, w szkołach, w instytucjach dobroczynnych i kulturalnych. Francesco Arcelli należał do tej właśnie kategorii osób duchownych, które łączyły, z lepszym lub gorszym skutkiem, służbę Bożą z zaangażowaniem o charakterze świeckim, publicznym i państwowym. W epoce nowożytnej tego rodzaju aktywność osób duchownych nie była niczym nadzwyczajnym, zwłaszcza w katolickiej monarchii hiszpańskiej.

\section{Słowa kluczowe}

Francesco Arcelli, zakonnik, Habsburgowie, Burbonowie, monarchia hiszpańska, katolicyzm 


\begin{abstract}
Francesco Arcelli, an Italian monk at the service of Bourbon Spain

The $18^{\text {th }}$ century was a time of considerable challenges for monastic life, both in general and for specific congregations. Let us recall such events as the abolition of Jesuit reductions in Paraguay, expelling Jesuits from Portugal and Spain, the dissolution of the Society of Jesus, the closure of hundreds of monastic houses as part of Josephine reforms or cruel repressive measures towards clergy during the French Revolution. Despite attempts at questioning the presence of orders in public space, they still played a significant role in many areas of social life, in the realm of culture and education. Despite service appropriate to monastic charismata, there were monks in royal courts, monks with important functions in state administration, in diplomacy, at universities, schools, charitable and cultural institutions. Francesco Arcelli was one of such monks, who combined, with better or worse results, serving God by their involvement in lay, public and state matters. In the early modern era such activity of religious orders was nothing extraordinary, especially among the Spanish Catholic monarchy.
\end{abstract}

\title{
Keywords
}

Francesco Arcelli, monk, the Habsburgs, the Bourbons, Spanish monarchy, Catholicism 


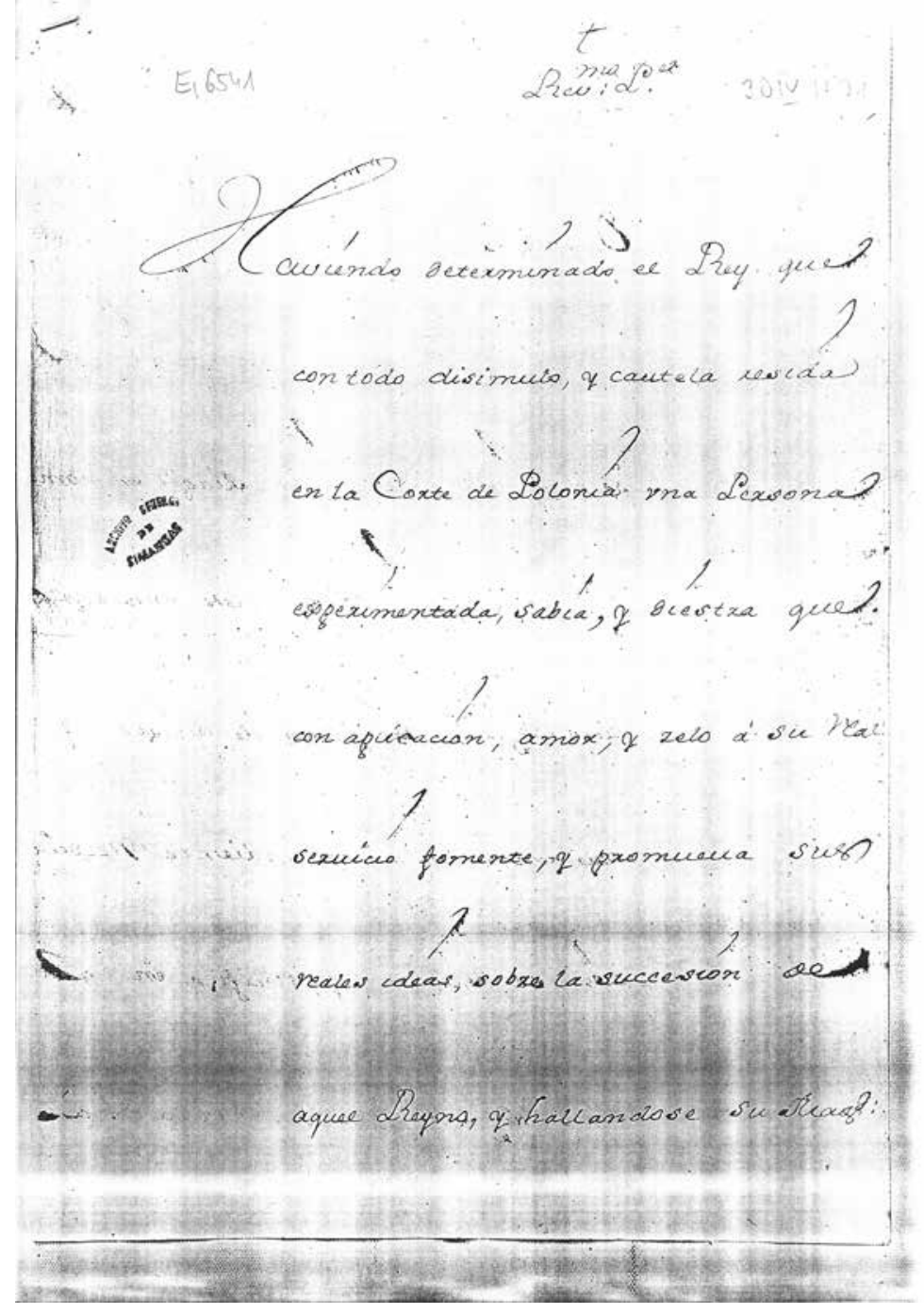

1. List markiza de la Paz do Francesco Arcellego, Sevilla, 30.04.1731. Wg Archivo General de Simancas, Estado, 6541 


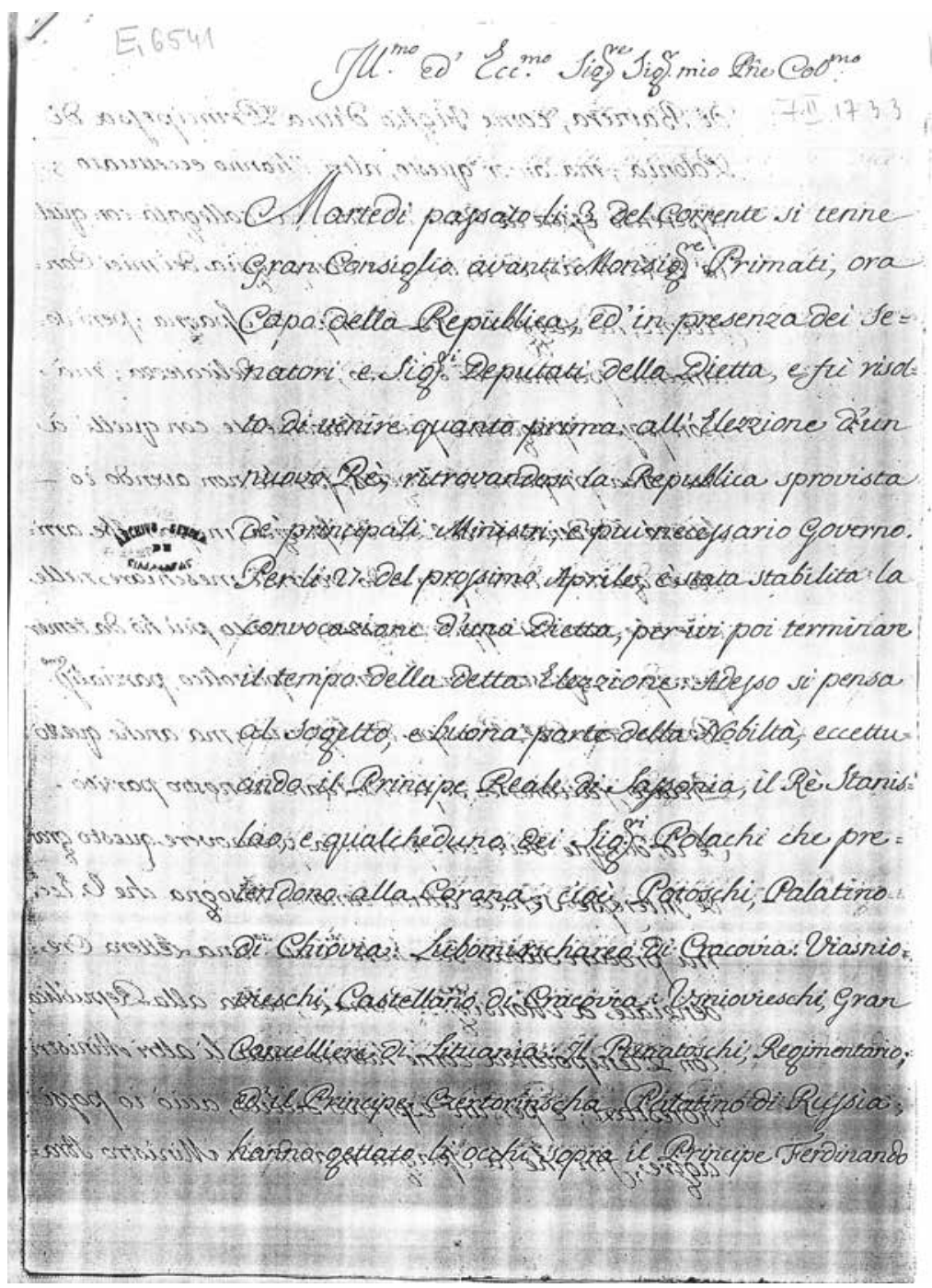

2. List Francesco Arcellego na temat sytuacji w Polsce, Warszawa, 7.02.1733. Wg Archivo General de Simancas, Estado, 6541 


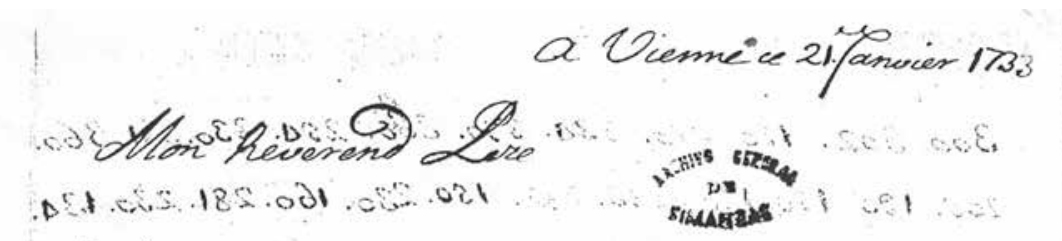

110. 190. 110.230.1 320.282.132.330. 240:280.140.282.

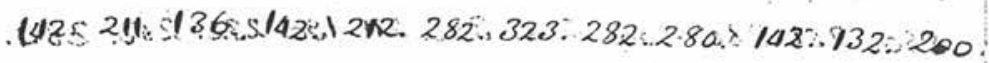
202.133. 190.150. 334. 330. 300.150. 230.1611190.300. $0^{2} 51.0380 .320,401.110 .16 \times 3.230 .272 .330 .330 .300$. 110.190 .150 .360 .291 .124 .230 .322 .142 .134230 .323$. 20.5 150. 280. 200. 134. 280, 282.300. 254.230.9141. 230. 132. 271. 334.330.360.0110.332. 368. 150. 330.110. 332. 130. 264.190.110.332.130.144.230.190.240. $302.250 .18 p_{1} \cdot 142.333 .110 .231 .150 .320 \div 150.175 .190$ $205.360,273.282 .300 .322 .190 .133 .130 .181 .280$. 172. 142 , 3.0. $110 \cdot 161.190 .282 .300 .145 .284 .190$ 214. 230. $211 \cdot 190.320 .282 .4100 \cdot 190.150 .205 .120$. 110. $19 \cdot 282.213 .300 .324 .330 .300 .334 .300 .251$

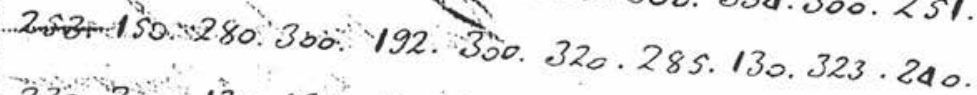
230.300 .130 .183 .160 .282 .150 .320 .110 .140 .282$.

3. Szyfrowany list księcia de Liria do Arcellego, Wiedeń, 21.02.1733.

Wg Archivo General de Simancas, Estado, 6541 


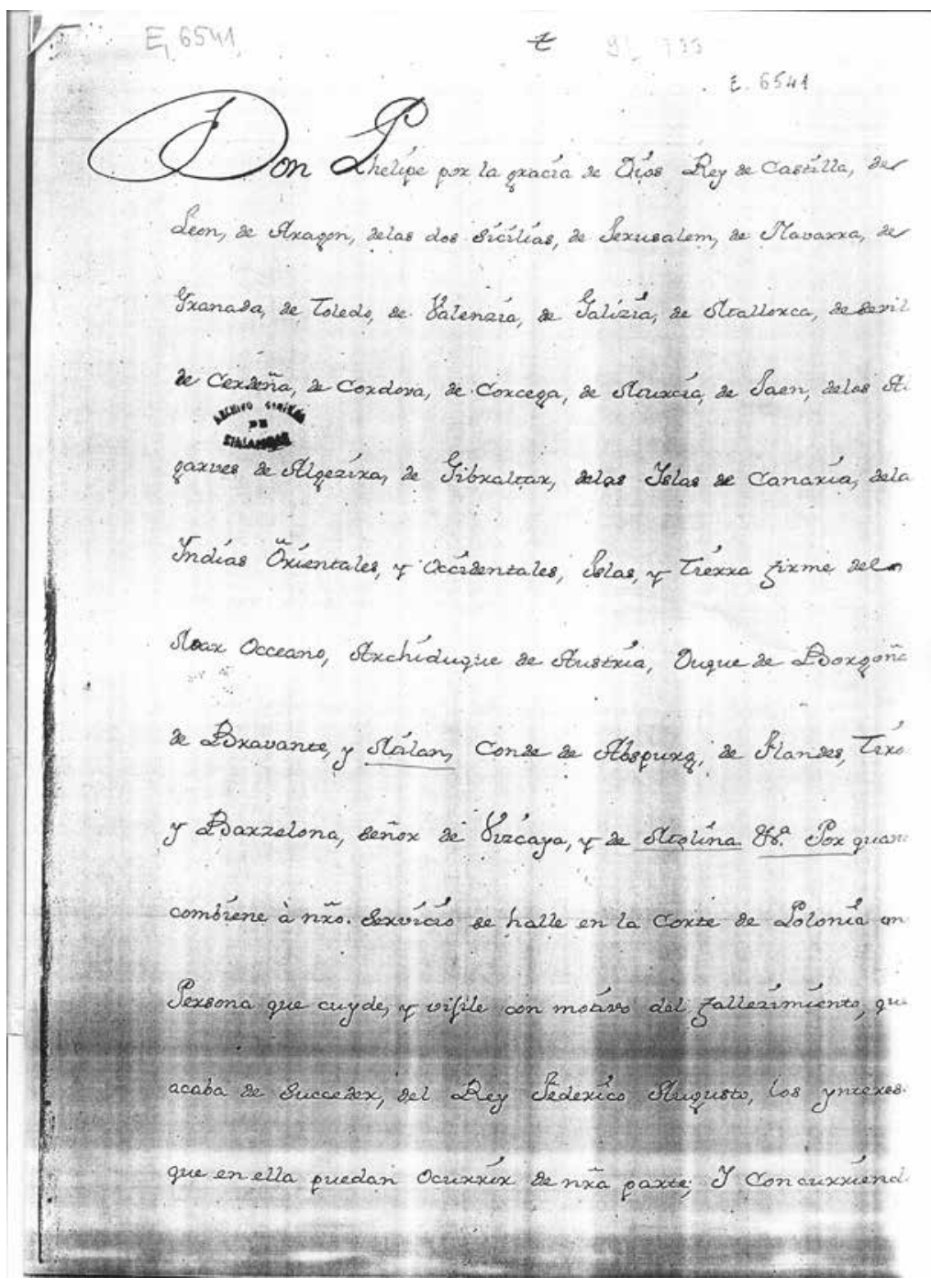

4. Akt nominacji Arcellego na ministra pełnomocnego w Polsce, Sevilla, 9.03.1733. Wg Archivo General de Simancas, Estado, 6541 